\title{
WNK1 Gene
}

National Cancer Institute

\section{Source}

National Cancer Institute. WNK1 Gene. NCI Thesaurus. Code C105602.

This gene plays a role in regulation of electrolyte homeostasis. 